\title{
HOGYAN ALAKÍTSUK KI A STATIKAI ÁLLAPOTOT MEGHATÁROZÓ SZAIKVÉLEMÉNYÜNKET
}

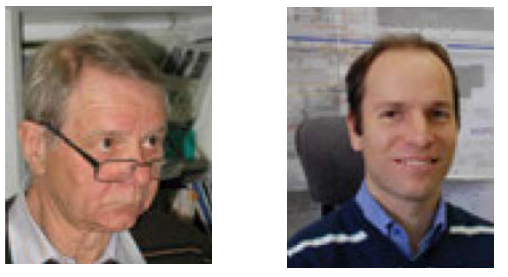

Dr. Almási József - Varvasovszky Péter

https://doi.org/10.32969/VB.2021.3.2

Egy meglévö épület átépitésének és felújitásának egyik legfontosabb tervezési eleme a tartószerkezet állapotát meghatározó statikai szakvélemény. Ennek elkészitéséhez ismernünk kell a jelenlegi jogszabályi és szabványi elöirásokat. A statikai szakvélemény támaszkodjon a helyszini szemlékre és vizsgálatokra, a tartószerkezet tüzvédelmi állapotának meghatározására és az erôtani számítás eredményeire. Véleményünk szerint ez utóbbi nélkül nem megalapozott az épület statikai állapotának minősitése. Tekintettel kell arra lenni, hogy a szakvélemény elsődleges célja az arról való nyilatkozás, hogy az épület hosszabb távon biztonságosan használható-e vagy sem, illetve milyen intézkedések szükségesek a hosszabbtávú hasznositáshoz.

Kulcsszavak: érvényes jogszabályok szabványok, statikai állapot, anyagvizsgálatok, tűzvédelem, ellenőrző számítás, földrengés vizsgálat, hosszútávú hasznositás

\section{BEVEZETÉS}

Magyarország épület állományának nagy rész közelít a 100 éves élettartamhoz, vagy azt meghaladó, különösen a nagyobb városok épületeinél, illetve középületeinél.

A használati szokások megváltozása, az új funkciók kielégítésének igénye egyre több feladatot jelent a tervezés területén is.

Ezért célszerünek és szükségszerünek látszik, hogy a meglévő épületek átépítésének, felújításának és sokesetben azok bővítésének statikai tervezési kérdéseinek áttekintés, a meglévő ismeretanyagok rendszerezése, az egységesebb tervezési szemlélet kialakításának segítése, a jelenleg érvényes jogszabályok és szabványok betartása érdekében.

Az átépítés, felújítás tervezés egyik első lépéseként a tartószerkezetek jelenlegi állapotát meghatározó statikai szakvélemény elkészítése elsődleges cél kell legyen, ami kellő alapot szolgáltat a tervezési feladat végrehajtásához. Ez a szakvélemény nem tévesztendő össze a ma szokásos használhatósági tanulmánnyal (Due diligence), amelynek csak egy általános részét képezi a tartószerkezet elemzése.

Az átépítés vagy helyreállítás tervezése során a tervezőnek számos jogszabályt és szabványt kell ismernie, amelyek a munkája során eligazítást adnak, cikkünk írása során ezekről is összefoglalót készítettünk.

\subsection{A megépült teherhordó szer- kezeteinek erőtani vizsgálata a korábbi MI 15011-1988 müszaki irányelv segítségével}

Sajnálatos, hogy még számos Kollégánk, ha egy meglévő épület átalakításáról, vagy felújításáról esik szó az korábbi MI 15011-1988 (MI, 1988) épületek megépült teherhordó szerkezeteinek erőtani vizsgálata, illetve ennek ,kissé felújított változatát" a MMK-TT TSZ-01-2010 (Dulácska et al, 2010) átmeneti időszakra kiadott szabványt emlitti hivatkozásként és tekinti elsősorban irányadónak, holott ma már újabb elöírások és kutatási eredmények léptek életbe, illetve állnak rendelkezésre.

Az idézett Müszaki Előírás mára már érvényét vesztette, az ott lefektetett vizsgálati elvek ugyan továbbra is érvényesek, az anyagszilárdságok meghatározás módszerei és értékelés területen is, de bővítésre szorul az elvégzendő erőtani számítások és az épület statikai állapotának besorolása területén figyelembe veendő szempontokból. A Müszaki előírás MMK-TT általi kiadása (TSZ-01-2013) egy átmeneti időszakra vonatkozott, mert ekkor még nem állt rendelkezésre az MSZ EN szabvány sorozat és különösen az MSZ EN 1998-3 szabvány, ami jelenleg elsősorban az irányadó.

\subsection{Az építés időpontjára vonatko- zó technikai ismeretek}

Az átépítés, felújítás során a Mérnök nem nélkülözheti az épület építésének időpontjában meglévő technikai ismereteket, azaz a felhasznált anyagok és azok gyártására (kezdve az acélgyártástól a cement és tégla előállításon át), és ezek minősítésére alkalmazott módszereket, az ismereteket a tartószerkezetek tervezése terén (statika, erőtani számítások), a rendelkezésre álló tartószerkezeti elemeket (acélgerendák, béléstestek, cementek-betonok, lépcsőelemek stb.) ismertető irodalmi adatokat.

Mindezekről korábbi könyvek és tudományos dolgozatok, kiadványokból, illetve levéltárakból lehet tájékozódni.

\subsection{A tudomány mai állásához iga- zodó mérnöki felfogás}

Az épületek átépítése és felújítása során a statikus tervezőnek célszerü a következőket mérlegelnie:

- a jelenlegi jogszabályi és szabványi előírások milyen megkötéseket tesznek, milyen az építési időszaktól eltérő szabályozást adnak, mert ezek között lényeges eltérések adódhatnak, 
- helyesen akkor járunk el, ha a mostani szabályozásoknak megfelelően végezzük az épület statikai felülvizsgálatát, mert az épület hosszabb távú használatát erre alapozhatjuk csak, (véleményünk szerint nem elfogadható az építéskori szabályozás szerinti felülvizsgálat),

- a statikai ellenőrzésnél lényeges szempont mind a teherbírások, mind a hatások értékeinek meghatározásánál alkalmazandó parciális tényezők értékeinek felvétele, a földrengés hatás kellő mértékü figyelembevétele, az épület anyagainak és csomóponti kapcsolatainak és a lehetséges duktilitás mértékének számbavétele, valamint az észszerủen vállalható kockázat nagyságának megállapítása,

- milyen új anyagok, és új építési technológiák állnak rendelkezésre az épület felújításéra és megerősítésére.

\subsection{Az ésszerő kockázat}

Az átépítések és felújitások tervezése során a mérnöknek lehetősége van az adott épület konkrét szerkezeti kialakitásának megállapítására és a tényleges anyagszilárdságok meghatározására és ebből a terhelések figyelembe vételével a szükséges biztonság megteremtéséhez alkalmazandó parciális tényezőknek a valósághoz való igazításával az ésszerü kockázat vállalására és gazdaságos megoldás megtervezésére (APFM Adjusted Partial Factor Method, és FORM analizis segítségével).

A tervező mérnök a társadalom felé felelősséggel tartozik, annak érdekeit az észszerüség határain belül védenie kell és ennek korlátjait a szabványok jelentik, illetve azokat kellően megalapozott tudományos értékélesékkel való helyettesítés. Ezért bizonyos mérlegelési lehetősége a mérnöknek is fennáll. Azonban rossz tanácsadó lehet, ha csak a saját tapasztalataira támaszkodik és az épület tartószerkezetének komplex viselkedését csak ez alapján kívánja meghatározni és nem támaszkodik az anyagvizsgálatok alapján elvégzett ellenőrző erőtani számításokra.

Mindezek részletesebb ismertetését az alábbiakban mutatjuk be.

\section{AZ ÉPÜLETEK ÁTÉPÍTÉSÉRE, FEL- ÚJIITÁSÁRA VONATKOZÓ JOG- SZABÁLYOK}

Az alábbiakban felsoroljuk a vonatkozó jogszabályokat melyeket a statikai állapot meghatározó szakvélemény kidolgozás során figyelembe kell vennünk:

Az építési törvény Étv 1997. évi LXXVIII. törv.

A 312/2012. engedélyezésről szóló kormányrendelet

A régészeti örökség és a mủemléki érték védelmével kapcsolatos 393/2012 (XII.20) korm. rendelet és azokban megfogalmazott betartandó követelmények, melyek idézésére itt nincs mód.

\section{AZ ÁTÉPÍTÉSRE, FELÚJÍTÁS- RA VONATKOZÓ SZABVÁNYI ELÖÍRÁSOK}

\subsection{Néhány szó a tartószerkezetek méretezéselméletéről}

A tartószerkezetek méretezését a lefektetett méretezés elméletek alapján végezzük, ezért ennek fejlődésének áttekintése célszerü az elmúlt időszak szabványi előírásainak tükrében.

Egy épület átépítésénél, átalakításánál, felújításánál első kérdésként merül fel, hogy az épület ezt követően tartósan biztonságos-e, és milyen időtartamra áll fenn ez a biztonság (élettartam).

A biztonság mértéke és értelmezése az elmúlt idöszakokban jelentösen változott, különösen mióta erőtani számításokkal vizsgáljuk az épület állékonyságát. Ennek kezdete az 1850es évekre tehető, amikor a mechanikai ismeretek, az épület tartószerkezeteinek mechanikája kialakult. Ezt megelőző időszakban a tartószerkezetek méreteit és kialakítását föleg tapasztalati úton, mesterségbeli tudás alapján határozták meg.

A mechanikai tudás bővülésével a tervezők egyre nagyobb pontossággal tudták a szerkezetek méretezését végre hajtani. Ehhez nagyban hozzásegített a méretezés elmélet fejlődése.

A II. világháborút megelőző időszakig az un megengedett feszültségeken alapuló méretezési eljárás volt használatos, amikor a szerkezetre müködő terhekbőll és igénybevételekből számított feszültség nem haladhatta meg az adott tartószerkezet anyagára megengedett feszültség értékét. A biztonság mértékét a megengedett feszültség és a fellépő feszültség hányadosa adta.

Ezt követte az un. osztott biztonsági tényezős eljárás, amikor egyrészt a terhek és geometriák meghatározásánál, másrészt az anyagszilárdságok meghatározásánál alkalmazunk különböző biztonsági tényezőt és elvárás volt, hogy az ily módon különböző teherkombinációkra biztonsági tényezökkel növelt mértékadó igénybevételek nem haladják meg a biztonsági tényezővel csökkentett határfeszültségből számítható határigénybevételek értékét. Itt a biztonság mértékét a határ igénybevétel és a mértékadó igénybevétel hányadosa adta.

Mivel a szerkezet erőjátékában szerepet játszó paraméterek általában nem jellemezhetők egyetlen számadattal (nem determinisztikus értékek), azok valószínűségi változók és bizonyos megbízhatósággal való meghatározásához a paraméterek eloszlás függvényeinek az ismerete szükséges. A ma használatos méretezési eljárás az osztott biztonsági tényezős eljárásból fejlődött ki, és félvalószínüségi eljárásnak nevezzük, amikor a méretezésben szereplö paramétereket valószínüségi változóknak tekintjük és a számításban szereplő paramétereket matematikai statisztikai módszerekkel határozzuk meg, lásd részletesen a 3.2 pont alatt.

\subsection{Tartószerkezetek tervezésének alapjai, az MSZ-EN 1990 szab- vány}

Ez a szabvány egyaránt vonatkozik új- és meglévő épületekre.

Lásd itt elsősorban az idézett szabvány 2.2. pontját az épület biztonsági, megbízhatósági szintjeire vonatkozó utalást.

A megbizhatósági szint teljesítését az új épületeknél használt igénybevételek (hatások) tervezési értékére $\left(E_{d}\right)$ használt számítási módszerek, teherkombinációk és parciális tényezők $\left(\gamma_{p}\right)$ és teherbirási (ellenállás) tervezési értékek $\left(R_{d}\right)$ valamint azok parciális tényezői $\left(\gamma_{M}\right)$ segítségével ellenőrizhetjük (Kovács et al, 2012).

Meglévő épület tartószerkezetének tényleges kialakításának ismerete esetén lehetöségünk van a nem a,„szabványos” parciális tényezőket célszerü használni (pl. az igénybevételek tervezési értékének csökkentése érdekében, vagy a teherbirás tervezési értéknek növelése érdekében), és ezeket a megbízhatósági eljárással (teljes valószínüségi módszer, ill. elsőrendü megbízhatósági módszer (FORM II:) segítségével érhetjük el (Beton Kalander, 2009 és Várdai, 2020) 


\subsection{Az MSZ EN 1998/3 -2013 Tar- tószerkezetek tervezése föld- rengésre, Épületek értékelése és helyreállítása (MszEN, 2013)}

A meglévő épületek átépítése, felújítása tervezéséhez fontos és sok Tervező Kolléga által kevésbé ismert szabvány kiemelten foglalkozik a meglévő épületek állékonyságának ellenőrzésével szeizmikus terhelés esetén. Ez a szabvány arra is felhívja a figyelmet, hogy a jelenlegi általános Magyarországi gyakorlattal szemben az átépítések és felújítások során az épület földrengés állóságával is foglalkozni kell. A korábbi tervezési gyakorlathoz (vagy szabványi elöírásokhoz) képest ez jelenti a legnagyobb változást és ennek helyes mértéktartó alkalmazása az átépítések és helyreállítások során kiemelt jelentőséggel bír.

Magyarországon alapvető követelmény a szerkezet károsodás mértékének korlátozása földrengés teherre: ez un. jelentős károsodási határállapot: $\boldsymbol{S D}=$ Significant Damaged (lásd a szabvány NA melléklet) (MSZEN, 2013)

Jelentős károsodás határállapota (SD) szerint: a tartószerkezet jelentös mértékben károsodott, a maradó szilárdság és merevség közepes mértékü, és a függöleges tartószerkezeti elemek képesek elviselni a függőleges terheket. A nem tartószerkezeti elemek károsodtak, azonban a válaszfalak és a kitöltöfalazatok nem szenvedtek olyan tönkremenetelt, mely a sikjukból való kitérést eredményezett volna. Tartós terhelés esetén közepes méretü szintek közötti vizszintes eltolódáskülönbségek alakultak ki. A tartószerkezet elviselhet egy közepes intenzitású sokkszerü hatást. A tartószerkezet javitása valószínüleg gazdaságtalan.

\subsection{Korábbi Ml 15011-1988 (Ml, 1988) irányelv szerint az épüle- tek megépült teherhordó szer- kezeteinek erőtani vizsgálata}

Az idézett Müszaki Irányelv mára már érvényét vesztette, de az ott lefektetett vizsgálati elvek érvényesek, az anyagszilárdságok meghatározás módszerei és értékelés területen is. A Müszaki előírás MMK-TT általi kiadása (TSZ-01-2010) egy átmeneti időszakra vonatkozott, mert ekkor még nem állt rendelkezésre az MSZ EN 1998-3 szabvány

Ezt az elöírást a 2013-ban megjelent és 3.2 pont alatt említett szabvány érvénytelenítette. Itt kell megemlíteni, hogy sok esetben Tervező Kollégák ezen elöírás alapján az un. "használati tapasztalatokra" való hivatkozással állékonynak tekintik az épületet, holott ez a meghatározás még számos egyéb feltétel teljesülést is megkívánja a 20 éves fennállásán túlmenően, mint a szerkezet előéletére vonatkozó adatok (tervek és iratok, üzemelői tapasztalatok, előző meghibásodások és vizsgálatok, korábbi funkciók stb.), átalakítások, helyszíni szemle tapasztalatai (alakváltozások, repedések), müködő terhek és hatások mértéke, a tartószerkezet statikai müködése és az abban rejlö tartalék (többtámaszú viselkedés, erő átrendeződés lehetősége) figyelembe vételét. Hozzá téve még az MI azon figyelmeztetését, hogy ezen igazolási mód megbizhatósága csak mérsékelt, és óvatosságra intö és nem nélkülözhetö a megállapításhoz az erőtani számítás.

\subsection{A ma érvényes szabványok szerinti állapot meghatározó statikai szakvélemény tartalmi követelményei}

Jelenleg a tartószerkezetek tervezése, ellenőrzése és átépítések, felújítások estében kötelező az MSZ EN, vagy azzal ezzel azonos eredményekre vezető eljárások, illetve kellöen megalapozott tudományos eredményekre támaszkodó, előírások, szabványok használata, az ezekben foglalt követelmények teljesítése.

Az átépítésre váró épület minősítését az alábbiak együttese adja meg:

- az épület általános állapota, melyet a tartószerkezeteteket alkotó anyagok szilárdsága, korróziója, az épület és tartószerkezet mozgásai (lehajlás, repedés, süllyedés), az épület lokális, vagy globális meghibásodásai, az épület élete során fellépő meghibásodások együttes elemzéséből határozhatunk meg,

- a tartószerkezetek tüzvédelmi állapota, melyet a betontakarások mértéke, a meglévő tüzvédelmi kialakítások segítségével elérhető tüzvédelmi időtartamot jelent,

- az épület erötani állapota, melyet az igénybevételek és ellenállások értékeléséből nyert megállapítások tehát statikai számítások alapján ismerünk meg.

Az előbb felsorolt három fö jellemzőnek együttes értékelése által tudjuk kialakítani szakértői megállapításunkat. Tehát az MSZ EN szabványban leírtkövetelmények összevetése útján szabad eljárnunk és nem a Szakértő egyéni, szubjektív, kevéssé tényszerü, inkább tapasztalati útján felállított kritériumok szerint.

Különösen igaz ez, ha megállapításunk érvényességét nem csak a jelen állapotra, hanem az épület hosszabb távú biztonságos müködtetése céljával határozzuk meg, ami egy átépítés során általános cél ( $\mathrm{pl}$ a szokásos 50 éves élettartam).

Hogy az elöbb felsorolt szempontoknak eleget tudjunk tenni és az épület tartószerkezetének állapot meghatározó szakvéleményét megalkossuk, az alábbiakban részletezettek szerint javasolt eljárni.

\section{AZ ELŐKÉSZÍTŐ VIZSGÁLATOK AZ ERŐTANI ELLENŐRZÉSHEZ}

Az átépítés, felújítás tervezésére szolgáló állapot meghatározó statikai szakvélemény elkészítéséhez igen fontos a meglévő épület tartószerkezetének tényleges kialakításának ismerete. A kialakítás szót itt szélesebb értelemben használjuk, ami a szerkezet geometriáját, a tartószerkezeti elemek anyagának és egymáshoz való kapcsolódásának (csomópontjainak) megismerését jelenti.

\section{1 Általános információk az épü- lettel kapcsolatosan}

Az épülethez kapcsolódó iratok és tervek, egyéb dokumentumok felkutatása. Ezek egyik lelőhelye lehet - a tulajdonosi irattárakon túlmenően - a városi, országos levéltárak. Jelenleg a Lechner Központ, ahol a korábbi épületek terveik összegyüjtésre kerültek. Fontos információkat adhatnak az épülettel kapcsolatosan korábban készült szakvélemények.

Célszerü tanulmányozni az építési időszakban érvényes szabványokat és előírásokat. 
A bizonytalanságok minimalizálása érdekében a különböző forrásokból származó adatokat egymással össze kell vetni.

Az általános tájékozódást segíti a Magyarországon előforduló korábbi földrengések tanulmányozása is.

\subsection{A kiindulási adatok az ellenőrző vizsgálatokhoz}

Általános esetben a következő adatokat kell beszerezni, illetve figyelembe venni:

az épület építészeti és tartószerkezeti tervei és müszaki leírásai

- a tartószerkezeti rendszer azonosítása, amit a helyszíni felmérésekkel és tervekkel pontosíthatunk,

- az épület alapozási rendszerének azonosítása és altalaj viszonyok azonosítása,

- az épület tartószerkezeti elemeinek geometriai méretei, valamint az alkotó anyagok és azok mechanikai tulajdonságai,

- szerkezeti és anyag hibák, nem megfelelő szerkezeti kialakítások,

- az eredeti tervezés során volt-e földrengés tervezés,

- az épület jelenlegi és jövőbeli funkciói,

- a tervezéskor figyelembe vett hasznos terhelések és egyéb hatások,

- esetleg a korábbi meghibásodások adatai és azok elhárításának módjai.

A helyszíni vizsgálatok során ezen adatok ellenőrzése és kiegészítése elősegíti az ellenőrzés megbízhatóságának növekedését, a bizonytalanságot csökkenti.

\subsection{Helyszíni szemlék és vizsgálatok}

4.3.1 Helyszíni szemle és megállapításai, helyszíni feltárások és fotó dokumentáció

A helyszíni szemle és vizsgálatok végzéséhez és azok azonosításához az épület tervei alapján vázlatokat célszerű előkészíteni, melyekre a tapasztaltak és mérési eredmények rögzíthetők.

A helyszíni vizsgálatoknál a következő szinteket különböztethetjük meg:

- korlátozott helyszini vizsgálat, amikor a tényleges szerkezeti kialakításokat a rendelkezésre álló részletes tervekkel való összevetést végezzük el, a 4.1 táblázatban adott szerkezeti vizsgálati szám mellett,

- kibővitett helyszíni vizsgálat, amikor az eredeti részletes tervek nem állnak rendelkezésre ekkor a 4.1 táblázatban adott számú vizsgálat végzendő el,

- átfogó helyszíni vizsgálat, amikor az eredeti részletes tervek nem állnak rendelkezésre, de egy magasabb megbízhatósági (ismereti) színtett szeretnénk elérni, ekkor a 4.1 táblázat szerinti vizsgálati szám szükséges.

A helyszíni szemle során megfigyeléseink az alábbi szempontokra terjedjen ki és dokumentáljuk azokat:

- a főbb tartószerkezeti elemek és a tervek egyezőségének ellenőrzése,

- a föbb tartószerkezeti elemek anyagának beazonosítása,

- a föbb tartószerkezeti elemek esetleges károsodásának megfigyelése (pl. oszlopokon függőleges repedése, gerendák hajlítási és nyírási repedései, lehajlások mértéke, teherhordó főfalak- falazatok nyírási repedései, korróziós károk, időjárás okozta károsodások stb.)

- épület általános állapota, süllyedésék és süllyedések okozta károsodások,

- konzolos szerkezetek megfigyelése,

- lépcsők, lépcsőszerkezet megfigyelése,
4.1 táblázat: Ajánlott minimális követelmények a különböző szerkezetvizsgálati és anyagvizsgálati szintekhez (MSZ EN-1998-3)

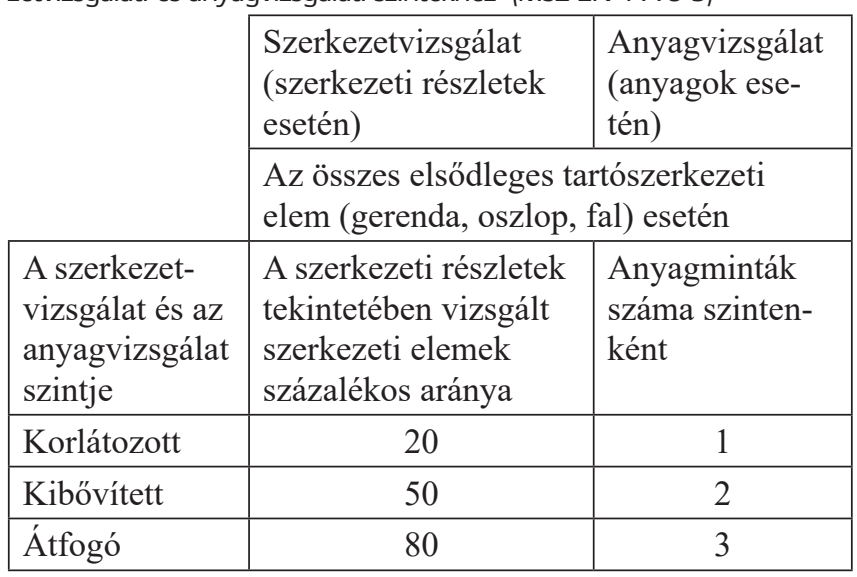

- esővíz és talajvíz okozta károsodások,

- környezeti ártalmat okozó anyagok jelenléte,

- az épület általános állapotát és föbb tartószerkezeteit bemutató fotó dokumentáció készítése.

\subsubsection{Anyag vizsgálatok}

A következő anyagvizsgálati módszerek javasolhatók.

\subsubsection{Roncsolásmentes anyagvizsgálatok}

Beton esetében a Schmidt kalapácsos mérés elfogadható, melynek segítségével a beton szilárdsági osztálya meghatározható

Acélanyagok esetében a Poldi kalapácsos vizsgálata lehetőséget nyújt a beazonosításra és az acél szilárdsági osztályának meghatározására.

Fontos szem elött tartani, hogy a roncsolásmentes vizsgálatokat igen egyszerü eszközökkel végezzük és a megbízható eredményeket csak kellő tapasztalattal és csak hitelesített kalibráló táblázatok (értékek) segítségével nyerhetünk, ezért célszerü erre hívatott, speciális ismeretekkel és tapasztalatokkal rendelkező Céget (Szakembert) megbízni. A jobb megbízhatóság érdekében a roncsolásmentes vizsgálatokat javasolt roncsolásos vizsgálatokkal kiegészíteni.

\subsubsection{Roncsolásos anyagvizsgálatok}

A roncsolásos anyagvizsgálatokhoz szükséges speciális berendezések és szakismeretek sok esetben nem állnak a tervező rendelkezésére. Ezeknek a vizsgálatoknak is kialakult eljárásrendje van, a feladat elvégzését Szakcégre szükséges bízni.

A célszerü minta vételi helyek kijelölése azonban a statikus tervező feladata.

\subsubsection{Falazatok anyagvizsgálata}

Külön szükséges szólni a falazatok anyagvizsgálatáról, mert a korábbi épületeink fontos tartószerkezeti elemét képezik, és hiteles vizsgálatuk sokkal bonyolultabb a falazat nagyfokú inhomogenitása miatt.

A helyszíni roncsolásmentes vizsgálatok eredményeit kellö óvatossággal kell kezelni, célszerübb nagyobb méretü faltest kivétele és laboratóriumi vizsgálatának végzése a falazat szilárdságának meghatározásra. A helyszíni terheléses vizsgálat segíthet egy viszonylag megbízható eredmény eléréshez. 


\subsection{Az ismereti szintek beazonosí- tása és értékelése az MSZ-EN 1998/3 szabvány 3.3 pont alapján (MSZN, 2013)}

A vizsgálatok alapjául szolgáló kiindulási adatok megbízhatóságának minőségi elbírálását az alábbiak szerint végezhetjük. Ennek eredményeként dönthetünk arról, hogy a parciális tényezőkön túlmenően további un. bizonytalansági tényezőt $\left(\mathrm{CF}_{\mathrm{KLi}}\right)$ alkalmazunk, vagy sem.

\subsubsection{Az ismereti szintek beazonosítása}

Az ismereti szintek beazonosítása a rendelkezésre álló geometriai adatok, a szerkezeti részletek (kapcsolatok, födémtárcsa elemei, koszorúk, válaszfalak), és a fö tartószerkezeti elemek állapota segítségével végezhetjük el.

\subsubsection{Kibővített helyszíni vizsgálatok:}

Vasbeton épület esetében, ha a tervek nem állnak rendelkezésre a tartószerkezeti elemek vasalásának meghatározása, illetve meglévő tervek esetében ellenőrzése, a korabeli tervezési részletek megismerése szükséges. Igen nagy körültekintést és tapasztaltot kíván meg.

Téglaépületek esetében a teherhordó falazatok és födémek kapcsolatának megismerése, a vízszintes koszorú rendszer kialakítás, az épület merevítése, falazat teherbírásának laboratóriumi vizsgálatához próbatest kivétele szükséges.

\subsubsection{Az ismereti szintek meghatározása}

Általában három ismereti szintet érdemes megkülönböztetni, KL1 korlátozott ismereti szint, KL2 szokásos ismereti szint, KL3 teljes ismereti szint (lásd a 4.2 táblázatnak megfelelően). $\mathrm{Az}$ ismereti szinteket meghatározó tényezők a következő:

- geometria, a tartószerkezeti rendszer (és nem a tartószerkezeti elemek) azon geometriai jellemzői, melyek a szerkezet globális állékonyságára van kihatással,

- szerkezeti részletek, amibe bele tartoznak a vb elemekben a vasalás mennyisége és kialakítása, acélszerkezenél az elemek kapcsolata, a födémtárcsák és oldalirányú megtámasztását biztosító szerkezetekhez a kapcsolata, a falazott szerkezetek tapadásos- (súrlódásos) és habarcs kapcsolatai, valamint a falazatok bármilyen vasalása,

- az anyagok és alkotóanyagok mechanikai jellemzői A tényezők rendezésével az alábbi táblázat állítható fel, amihez az ismereti szintek és a bizonytalansági tényező $\mathrm{CF}_{\mathrm{KLI}}$ közötti kapcsolat rendelhető (MSZ EN 1998-3)

A táblázat szereplő paraméterek fontos jelzést adnak a szakértőnek a megszerzett adatok és az elvégzett vizsgálat eredményeinek megbízhatóságáról.

Az ellenőrző erötani számítás végzésérhez kapcsolódó elökészitő vizsgálatok összefoglalása kapcsán kimondhatjuk, hogy a helyszíni szemlék és anyagvizsgálatok eredményei nagyban hatással vannak az állapot meghatározó statikai szakvéleményben tehető megállapításokra, mert ezen eredmények megbízhatósága a szakvélemény hitelességét jelentősen növelhetik, vagy csökkentik.

A szerkezetek tényleges kialakitásának a megismerése, a meglévő tervekkel való összevetése és a helyszíni tartószerkezeti „válaszok” (repedések, lehajlások) az elmúlt időszakból a helyes számítási modell felvételét biztosítja. A számítás végrehajtásához szükséges geometriai adatok, anyagszilárdsági értékek tényleges értékeinek meghatározása csak jelentős munka árán állapítható meg, ez időt és költségtérítést igényel, amit számos esetben a megbízók alábecsülnek és nem tartanak fontosnak, de ezt a statikus szakértö nem fogadhatja el, mert a végsö megállapitásokért jelentös felelöséget visel.

\section{A TARTÓSZERKEZETEK MEGLÉVŐ TÚZVÉDELMÉNEK BIZTOSÍTÁSA ÉS ELLENŐRZÉSE}

A tartószerkezetek állapotának meghatározásához hozzátartozik a szerkezeti elemek feltárása tüzvédelmi szempontok szerint. A meglévő szerkezet tűzvédelmi állapotát anyagféleségek szerint és korábbi tüzvédelmi kialakítások szerint határozhatjuk meg.

\subsection{A tartószerkezetek jelenlegi tǔzvédelmi állapota és várható tüzvédelmi időtartamok}

A tartószerkezetek tüzvédelmének biztosítás szabványi követelmény. Ez a tartószerkezet oldaláról nézve azt jelenti, hogy az elöírt tüzvédelmi időtartamot biztosítani kell.

Az épületen belül az egyes tartószerkezetek tüzvédelmi időtartamait a Tủzvédelmi szakvélemény szokta tárgyalni, amelyet egy új szerkezet kialakításánál figyelembe vesz a statikus tervező.

Az átépítések tervezésénél, különösen a statikai állapot meghatározó szakvélemények készítésének időpontjában csak igen elöre látó Megbízó esetében áll rendelkezésre tüzvédelmi szakértési eredmény. Így legtöbb esetben a statikus szakértő kell, hogy becslési jelleggel állítson fel a tartószerkezetekre vonatkozó tűzvédelmi időtartam táblázatot.

Ennek elkészítéséhez az épületet tüzvédelmi osztályba kell besorolni, a hatályos 54/2014. (XII. 5.) BM rendelet [OTSZ] ezek szerint az épület alacsony (AK), közepes (a KK) és magas kockázati (MK ) osztályba sorolható.

A kockázati osztályok alapján írható elő az épületen belül egyes tartószerkezetre vonatkozó tüzvédelmi időtartam követelmény.

Ezt követően határozhatók meg az épület jelenlegi tüzvédelmi megoldásai által biztosítható tüzvédelmi időtartamok, a szerkezeti kialakítások segítségével.

Helyszíni vizsgálatokból a szerkezetek jelenlegi tűzvédelmi állapotára az alábbi jellemzők alapján következtethetünk:

az épületek tartószerkezeteinek tüzvédelmére az építés időszakában, pl. a beton szerkezeteknél az alkalmazott betontakarások, az acélszerkezeteknél a tüzvédő festésből, vagy egyéb tüzvédő anyagból,

- a betonnal kombinált acélszerkezetek esetében (öszvérszerkezetek) esetében az acélszerkezet betonba való beágyazottsága segítségével,

- az acélszerkezetű oszlopok esetében az alkalmazott tüzvédelemi rétegekből.

A vizsgálat eredményeként táblázatot állíthatunk össze az egyes szerkezeti elemekre vonatkozóan a meglévő tüzvédelmi teljesítmény (állapot) és a várható tüzvédelmi követelmény között. Ezek összevetése segítségével dönteni lehet a szükséges tűzvédelmi megoldásról, példaként az alábbi táblázatot említjük. 
4.2. táblázat: Ismerteti szintek és az azokhoz tartozó vizsgálati módszerek (LF: vízszintes erők módszere, MRS: modális válaszspektrum-analízis) és bizonytalansági tényezők (CF)

\begin{tabular}{|c|c|c|c|c|c|}
\hline $\begin{array}{l}\text { Ismereti } \\
\text { szint }\end{array}$ & Geometria & Szerkezeti részletek & Anyagok & Vizsgálat & $\begin{array}{l}\text { CF } \\
\text { bizonytalansági } \\
\text { tényező }\end{array}$ \\
\hline KL1 & \multirow{2}{*}{$\begin{array}{l}\text { Az eredeti } \\
\text { vázlattervekből, } \\
\text { kiegészítve } \\
\text { mintavételen } \\
\text { alapuló } \\
\text { szemrevétele- } \\
\text { zéses } \\
\text { felméréssel vagy } \\
\text { teljes felmérés } \\
\text { alapján }\end{array}$} & $\begin{array}{l}\text { A vonatkozó építési gyakorlattal } \\
\text { összhangban lévő tervezés } \\
\text { és } \\
\text { korlátozott helyszíni szerkezetvizsgálat } \\
\text { alapján }\end{array}$ & $\begin{array}{l}\text { A korabeli elöírások szerinti } \\
\text { járatos értékek alapján } \\
\text { és } \\
\text { korlátozott helyszíni } \\
\text { anyagvizsgálat alapján }\end{array}$ & $\begin{array}{l}\text { LF vagy } \\
\text { MRS }\end{array}$ & $\mathrm{C}_{\mathrm{FKL}} 1$ \\
\hline KL2 & & $\begin{array}{l}\text { A hiányos eredeti részlettervekből, } \\
\text { kiegészítve korlátozott helyszíni } \\
\text { szerkezetvizsgálattal } \\
\text { vagy } \\
\text { kibövített helyszíni szerkezetvizsgálat } \\
\text { alapján }\end{array}$ & $\begin{array}{l}\text { Az eredeti tervezési } \\
\text { elöírásokból korlátozott } \\
\text { helyszíni anyagvizsgálattal } \\
\text { kiegészítve } \\
\text { vagy } \\
\text { kibövített helyszíni } \\
\text { anyagvizsgálat alapján }\end{array}$ & Tetszőleges & $\mathrm{CF}_{\mathrm{KL} 2}$ \\
\hline
\end{tabular}
$\mathrm{CF}_{\mathrm{KL} 1}=1,35, \mathrm{CF}_{\mathrm{KL} 2}=1,20$ és $\mathrm{CF}_{\mathrm{KL} 3}=1,00$.

\begin{tabular}{|l|l|l|}
\hline Szerkezeti elem & $\begin{array}{l}\text { Tüzvédelmi } \\
\text { teljesítmény meglévő } \\
\text { állapotban }\end{array}$ & $\begin{array}{l}\text { Várható tüzvédelmi } \\
\text { követelmény }\end{array}$ \\
\hline Födém & REI60 & REI90 \\
\hline Fióktartó & R30 & R90 \\
\hline Fötartó & R30 & R90 \\
\hline Oszlop & R15 & R90 \\
\hline
\end{tabular}

Osszefoglalásként megállapithatjuk, hogy a tüzvédelmi elöírások egyre szigorodó volta feltétlen indokolttá teszi a tartószerkezet állapotának meghatározását a felülvizsgálat során és egyik fontos mérlegelési szempontot az épületről alkotandó véleményben.

A tartószerkezeti elemek tényleges tüzvédelmi állapotának meghatározása kapcsán arra a következtetésre juthatunk, hogy a szerkezet további felhasználhatóságának lehetőségei ezen állapot által és a megállapított szükséges beavatkozások között szoros összefüggés van, tehát számításba kell venni akár az épület új funkcióinak kialakítása, akár a szerkezetek megerősítése során a szerkezet tüzvédelmének biztosítását.

\section{AZ ELVÉGZENDŐ ELLENŐRZŐ ERÖTANI SZÁMÍTÁS}

Azállapot meghatározó statikai szakvélemény megállapításainak egyik alappillére az elvégzett ellenőrző erőtani számítás (pl. Magistrat Wien, 2008).

Az ellenőrző erőtani számítás feltétlen részét kell, hogy képezze az épület statikai állapot meghatározó szakvéleménynek.

Az erőtani számítást két alapvető állapotra, a statikus és szeizmikus állapotra kell elvégezni, ezeken belül a szabványokban adott teherkombinációkra, állandó és tartós, valamint használati teherkombinációra.

\subsection{Az épületek kockázati besoro- lása}

A meglévő épületek átépítése és felújítása során elvégzendő statikai ellenőrzések részben az épület méretétől függetlenek, de részben azok méretétöl függőek lehetnek.

Így különbséget tehetünk az 1-2 szintes, a 4-6 szintes és a 6 szintnél magasabb épületek között abból következően, hogy az állékonyság elvesztése milyen mértékü személyi veszteséggel jár.

Minden esetben vizsgálandónak tartjuk az alapozás, a falak és oszlopok, valamint a födémek ellenőrzését, összehasonlítva az átépítés előtti, illetve az átépítés utáni statikai állapotokat.

Az elvégzendő ellenőrző erőtani számításokat az átépítendő épület besorolási szempontjai szerint kell végezni.

A besorolási szempontok a következők lehetnek:

- a választott kárhányad (MSZ EN 1900 szabvány B1 táblázat: CC)

- a megbízhatósági szint (MSZ EN 1900 szabvány B2 táblázat $\mathrm{RC}$ )

- a földrengési besorolás -fontossági osztály (lásd MSZ EN 1998-1)

- az elfogadott károsodási határállapot (lásd MSZ EN 1998$3 \ldots . . . \mathrm{SD})$

- anyagok teljesítő képessége (anyag szabványok: beton, betonacél, szerkezeti acél, kötőelemek, falazóelemek, kötőanyagok, faanyagok stb.) amit az anyagszabványok határoznak meg

- tüzvédelmi besorolás (AK, KK, MK)

- geotechnikai besorolás (geotechnikai kategória 1,2,3, és állapotok GEO, STR, EQU, UPL).

A számítások paramétereinek megválasztása során egymással összekapcsolódó tényező az épület választott kárhányada szerinti besorolás (MSZ EN 1990 B melléklet CC osztályok), a földrengés vizsgálatnál az épület fontossági osztálya (MSZ EN 1998-1 ...4.2.pontban 4.3 táblázat), az altalajosztály szerinti szorzó (MSZ EN 1998-1 3.2.pontban a 3.3 táblázat), és a csökkentett talajgyorsulás referencia értékének megválasztása (MSZ EN 1998-3.NB Nemzeti Melléklet $\mathrm{a}_{\mathrm{gRd}}$ értéke). 


\subsection{Az erőtani számítás alapelvei, számítási modellek felállítása}

Bár ezek az alapelvek a tervezői gyakorlatból jól ismertek, mégis célszerü ezeket ismételten is áttekinteni.

\subsubsection{Az erőtani számtás alapelvei}

Az erőtani számítás alapelvei az alábbiak, lásd MSZ EN 1990 és TT-MSZ 15011-2010.

Az erőtani modell felvételénél általában az eredeti tervek, illetve eredeti számítások adatai alapján kell felvenni, ha azok nincsenek ellentmondásban a szemrevételezéssel szerzett vagy a szerkezet típussal kapcsolatos tapasztalatokkal.

Ha eredeti számítások nem állnak rendelkezésre, akkor a mérési és feltárási eredményekre, alakváltozási és repedési jelenségekre kell támaszkodnia számítás végzése során.

\subsubsection{A számítási model}

Ugyan a mai mérnöktársadalom már hosszú évek óta használja a számítástechnika áldásait, tapasztalatunk szerint érdemes napienden tartani a kérdéskört.

Általános szempont a modell felállitásánál, statikus hatások modellezése

Az erőtani vizsgálatokat az épület tartószerkezetére jellemző összes változót tartalmazó modellen kell végrehajtani.

A modell tükrözze a tartószerkezet tényleges viselkedését a lehető pontossággal.

A modelleket az elméleti és gyakorlati mérnöki ismeretek alapján kell felépíteni.

A tartószerkezet statikus állapot vizsgálatára szolgáló modell az erő-alakváltozás összefüggést kövessen, a tartószerkezeti elemek egymás közötti és a talajjal való kapcsolatainak megfelelö megválasztásán alapuljon

A tartószerkezet dinamikus állapot vizsgálatára szolgáló modellt úgy kell felépíteni, hogy az minden tartószerkezeti elemét, azok tömegét, szilárdságát és csillapítási jellemzőit vegye figyelembe. A modell pontosságát növeli, ha a nem tartószerkezeti elemek is a nekik megfelelő jellemzőkkel a modellbe kerülnek. A modellezés tükrözze a tartószerkezet tényleges peremfeltételeit, valódi kényszereit.

Ha a dinamikus hatások olyan amplitúdójú vagy olyan frekvenciájú rezgéseke okoznak melyek a használati határállapotokban megengedett értékeket meghaladják, akkor az erre vonatkozó használhatósági határállapot igazolását el kell végezni.

\subsection{Az épület vizsgálata statikus állapotra}

Ezek részletezését itt nem ismertetjük, hiszen az általános statikusi gyakorlat mindennapi részei és itt csak a kapcsolódó szabványra utalunk.

Az általános elveket rögzítő MSZ EN 1990-2005 szabványon túlmenően, a terhelések szabványa (MSZ EN 1991 és részei), továbbá az egyes szerkezetek anyagaira vonatkozó tervezési szabványok szerint kell eljárni, így a falazott szerkezeteknél az az MSZ EN 1996-1-1, a vasbeton szerkezeteknél az MSZ EN 1992-1-1, az acélszerkezeteknél MSZ EN 1993-1-1 szabvány szerint.

A szerkezet megfelelőségét a teherbírási (ULS) és haználhatósági (SLS) határ állapotban kell igazolni.
$\mathrm{E}_{\mathrm{d}} \leq \mathrm{R}_{\mathrm{d}} \quad$ illetve $\quad \mathrm{w}_{\mathrm{SLS}} \leq \mathrm{w}_{\mathrm{ad}}$

Amennyiben a teherbírási és használhatósági követelmények nem teljesülnek az épület további használatára vonatkozó intézkedési javaslatot kell kidolgozni.

\subsection{Az épület vizsgálata dinami- kus, azaz földrengés állapotra}

A 2010-ben bevezetett új MSZ EN szabványok e tekintetben lényegesen új helyzetet teremtettek az új épületek tervezése területén, de nem adnak egyértelmű elöírást a cikkünkben vizsgált átépítések és felújítások esetében, amivel csak időben később megjelent MSZ EN 1998-3 szabvány foglalkozik. Ezért indokolt, hogy ezzel itt részletesebben foglalkozzunk, különösen azért is, mert a korábban, vagy még korábban épületek esetében feltehetően ezen hatásra való tervezés nem történt meg (SIA, 2005: BWG-Biel, 2005).

\subsubsection{Mikor indokolt a földrengés vizsgálat}

Közismert, hogy Magyarországon a MI-04.133-78 müszaki irányelv megjelenése (1978) előtt az épületek földrengés méretezése nem volt kötelező. Mivel a jelenlegi épületállomány jelentős része jóval ezelőtti időszakban épült, mondhatjuk az 1850-1860 évektől kezdődően, tehát már 100 év élettartamot jelentősen meghaladóak és ebből következően ezek felújítása és átépítése napjainkban egyre gyakoribb és az új szabályozások értelmében (lásd építési törvényt és az MSZ EN szabványokat) az átépítés vagy felújítás során a földrengés állóságot vizsgálni szükséges.

Az épületek tulajdonosai igen különbözőek, vegyes, - magán tulajdontól kezdve az állami tulajdonig. Ebből következően az anyagi lehetőségek is igen erősen változóak.

A magán tulajdoni ingatlanoknál a tulajdonos felelőségére szükséges a tervezőknek felhívni a figyelmet, az épület földrengés veszélyességének mértékére és annak esetleges következményeire. De jelentősebb átépítéseknél a tervezőnek számítania kell arra, hogy a szabvány követelményeinek nem teljesítése a tervezés során az ő felelőségét is felveti. Manapság gyakori az ilyen típusú vita a tervező és Megbízó között. De olyan esetekkel is találkozhatunk, ahol maga a Tervezö nincs kellö figyelemmel az elöirásokra és azok betartását mellözi, vállalva annak kockázatát hogy teljes mértékben megszegi a jogszabályi elöírásokat és a társadalommal szembeni kötelezettségét.

A köztulajdonba lévő épületek, mint pl. korházak, iskolák, tüzoltóság és közintézményi irodaházak, hotelek esetében az ott dolgozók nagy száma miatt nem lehet eltekinteni a földrengés vizsgálattól és annak erőtani következményeit a tervezőnek az illetékesekkel közölni kell megoldási javaslat kíséretében.

Abban az esetben, ha nem végzünk földrengésszámítást az épület vízszintes irányú terhekre való állékonyságát értékelhetjük a földrengés szabványban megadott szerkesztési szabályoknak való megfelelés segítségével. Ilyenek lehetnek a fófalak méretei, azok egymáshoz képesti irányai és száma, vagy a födém tárcsaként való viselkedésének vizsgálata, továbbá az építési időszakban a szerkezetek kialakítására vonatkozó szerkesztési szabályok elemzése, összevetése a jelenkori szabályokkal. Segítségül szolgálhat ilyen esetben a földrengés károk tanulmányozása, melyekből az irodalmakban számos található. Azonban ezen eljárás csak elözetes vélemény kimondására szolgálhat, végleges megállapítások csak földrengés hatásra való vizsgálattal lehetséges. 
A szeizmikus erőtani vizsgálatok elvégzéséhez igen komoly elméleti és gyakorlati ismeretek szükségesek. Szerencsére a mai számítógépes programok az első feltételnél kisegítik a tervezőt, azonban a számítási modell összeállításánál, a számítási eredmények értékelésénél már a tervezö gyakorlati ismeretei dominálnak.

Mivel ezek a számítások ezen túlmenően hosszadalmas előkészületeket is kívánnak, sok esetben célszerü lehet az „egyszerüsítő” módszereket (kvázi kézi számításokat) előnyben részesíteni (lásd helyettesítő vízszintes erők módszerét), és ezen eredményeinek ismeretében dönteni a részletesebb számítás elvégzéséről kisebb szintszámú és jelentőségü épületek esetében.

A részletesebb vizsgálatokhoz az igénybevételeket:

a. a teljes szeizmikus hatásra, vagy

b. a q viselkedési tényezőn alapuló eljárással (csak duktilis viselkedésre képes anyagnál alkalmazható), - amikor q tényezővel osztott igénybevételt veszünk figyelembe (lásd MSZ EN 1998-1 szabvány 2.1, ill. 4.2 pontját)

A szerkezet megfelelöségének igazolása:

- a duktilis anyagoknál az alakváltozási képesség meghatározásával és összehasonlításával történhet, illetve

- rideg anyagoknál a teherbírási képesség és az igénybevétel tervezési értékével való összehasonlítással történhet.

Szeizmikus hatás csökkentett kiinduló értékének meghatározása

Megépült épületek esetében lehetőségünk van arra, hogy a szeizmikus hatás mértékét az MSZ EN 1998-3 szabvány NB mellékletében foglaltak szerint vehetjük fel az épület jelenleg várható élettartama és a tervezett további élettartam függvényében az alábbika szerint:

NB2. A meglévő épületekre vonatkozó $T_{N C R}$ visszatérési időket az épület várható további $T_{v}$ élettartama és a Tt $t_{\text {erv }}$ tervezési élettartama hányadosaként képzett $a=T_{v}^{e r v} / T_{\text {terv }}$ csökkentö szorzóval szorozva lehet meghatározni. A talajgyorsulási referenciaértékeket ennek megfelelöen csökkentett értékkel szabad figyelembe venni.

NB2.1. A $30 \%$-os túllépési valószinüséghez $\left(P_{N R C}=30 \%\right.$, $T_{N C R}=150$ év) az $a_{g R}$ NB1 szerinti talajgyorsulási értéknek mintegy 0,7 szerese tartozik.

NB2.2. A $40 \%$-os túllépési valószínüséghez $\left(P_{N R C}=40 \%\right.$, $T_{N C R}=100$ év) az $a_{g R}$ NB1 szerinti talajgyorsulási értéknek mintegy 0, 6 szerese tartozik.

NB2.3. A $50 \%$-os túllépési valószínüséghez $\left(P_{N R C}=50 \%\right.$, $T_{N C R}=75$ év) az $a_{g R}$ NB1 szerinti talajgyorsulási értéknek mintegy 0,5 szerese tartozik.

NB2.4. A $60 \%$-os túllépési valószinüséghez $\left(P_{N R C}=60 \%\right.$, $T_{N C R}=50$ év) az $a_{g R}$ NB1 szerinti talajgyorsulási értéknek mintegy 0,4 szerese tartozik.

Úgy gondoljuk, hogy az épület tulajdonosának, az átépítés megrendelöjének lehetősége eldönteni, hogy az épület tervezett további élettartamát milyen értéküre kívánja meghatározni és ennek függvényében a fenti adatok segítségével a földrengés hatás mértéke számítható. Ha tehát pl. a meglévő épület tovább élettartamát 30 évre és a tervezett élettartamot 50 évre tervezzük, akkor a földrengés visszatérési időre $T_{\mathrm{NRC}}=100$ évet kapunk és a $\mathrm{P}_{\mathrm{NRC}} 40 \%$-os túllépési valószínüség mellett a talajgyorsulás referencia értékét 0,6 szorosra vehetjük fel, azaz a tervezési talajgyorsulás $a_{g R D}=0,6 a_{g R}$ értékü lesz.

A $q$ viselkedési tényező́kön alapuló vizsgálat esetében a tervezési spektrumot az MSZ EN 1998-1 szabvány 3.2.2.5 szakasza szerint kell felvenni és a q tényező értékei vasbeton és acélszerkezetnél 1,5 és 2,0 lehet, falazott szerkezetnél 2,0 $-2,5$ lehet.

A szeizmikus hatás tervezési értékét kombinálni kell egyéb megfelelő állandó és esetleges terhelésekkel.

\subsubsection{A szeizmikus igénybevételek tervezési értékének meghatározása}

Mint korábban említettük az MSZ EN 1998-3 4.4 pontja alapján

- a vízszintes erők módszerén alapuló vizsgálattal, vagy

- a válaszspektrum segítségével

- lehet a szeizmikus igénybevételeket meghatározni. A válaszspektrumot az MSZ EN 1998-1 szabvány 3.2.2.2 pontja szerinti (q tényezővel nem csökkentett spektrum).

A számításokat az MSZ EN 1998-1 szabvány 4.3 pontja szerint kell végrehajtani.

\subsubsection{A teherbírás és biztonság igazolása a szeizmikus ál- lapotban}

A szeizmikus tervezési állapotban azállékonyság követelménye (teherbírási határállapot) akkor tekinthető teljesítettnek ha a szerkezet a teherbírás, a globális egyensúly ( beleértve a felborulást és elcsúszást) a szerkezet egésze megfelelő duktilitású ( az anyagok olyan tulajdonságokkal rendelkeznek, hogy képlékeny csuklók ki tudnak alakulni, ridegtörés és a lágy szintek kialakulása kizárt), a födémtárcsák olyan többletszilárdsággal rendelkeznek, hogy a szeizmikus hatás okozta vízszintes igénybevételeket a merevítő elemekre képesek átvinni, a szerkezet alapozása az MSZ EN 1998-5 szabvány szerinti követelményeket (talajtöréssel szembeni követelményt, elcsúszás elleni követelményt) teljesíti.

A szerkezet szeizmikus hatásra jelentős károsodási határállapotba is juthat (jelentősen károsodik, de nem omlik össze) amikor az igazolást elsősorban az összeomlást akadályozó elemek (oszlopok és falak, merevítő falak) duktilis viselkedés képessége (alakváltozási képessége) tudja megakadályozni, tehát az alakváltozások és az alakváltozási képesség (határalakváltozás) összehasonlítása alapján döntünk a szerkezet megfelelőségéről.

alakváltozások összehasonlítása $\mathrm{w}_{\mathrm{Rd}} \geq \mathrm{w}_{\mathrm{E}} \quad$ (oszlopok, falak, merevítés esetében )

illetve a teherbírások összevetésével $\mathrm{R}_{\mathrm{d}} \geq \mathrm{E}_{\mathrm{d}}$ (gerenda, födémlemez esetében)

\subsubsection{A szeizmikus erőtani számítás eredményeinek ér- tékelése}

Amennyiben a 6.4 .5 pont alatt adott relációk teljesülnek, úgy a tartószerkezet megfelelőségét tudjuk megállapítani.

Amennyiben nem ez a helyzet, tehát a relációk nem teljesülnek, úgy az irodalmi hivatkozásban közölt (Beurteilun der Erdbebensichertheit 2005, Biel) svájci ajánlás alapján a következők szerint járhatunk el.

Megállapítjuk az igénybevételek, alakváltozások hányadosát: (amit nem teljesülési hányadosnak nevezhetünk) - az igénybevételekből $\alpha_{\text {eff }}=R_{d} / E_{d} \quad$ vagy - az alakváltozásokból $\alpha_{\text {eff }}=\mathrm{w}_{\mathrm{Rd}} / \mathrm{w}_{\mathrm{E}}$

A hányadosok értékét az alábbi grafikon segítségével értékeljük az épület fontossága (BWK) figyelembevételével, egy adott minimális $\alpha_{\text {min }}$ és egy elfogadott $\alpha_{\text {adm }}$ küszöb értékek vonalai között. Az $\alpha_{\min }$ értéke az I. és II. fontossági 
osztályú épületeknél 0,25 , míg a III. és IV. fontossági osztályú épületeknél 0,4. Ez az alsó küszöb érték az észszerüen vállalható kockázat (nagyobb előfordulási valószínüség) mellett választott érték, melyre befolyással van a személyi veszteség (az emberélet „értéke, lásd Kármán Tamás korábbi okfejtését), az épület helyreállítási és a mentéssel összefüggő költségek, annak feltételezésével, hogy mind az épület, mind a személyek további 40 évig szolgálnák a társadalmat). A felső $\alpha_{\text {adm }}$ küszöb érték az épület tervezett tovább használatától függ, hosszabb távú használatnál az érték egyre jobban közelít az 1,0-hez.

A követelmények nem teljesülése esetén a szabványos értékhez képest a kockázat növekszik. Kockázatot befolyásoló tényezőnek tekinthetjük az épület helyszínének földrengés veszélyezettségét, az épület sérülékenységét, a károsodás következményeit.

Mind emellett az ésszerü kockázat választásnál mérlegelni szükséges a tartószerkezeti elem típusát, nem tehető engedmény az olyan tartószerkezeti elemnél, amely az épület globális meghibásodáshoz vezet (mondhatjuk progresszív összeomlást okoz, pl. oszlop, merevítés, lépcsőház), míg engedékenyebbek lehetünk egy födém esetében, ahol ez a jelenség nem áll fenn általában és a használat korlátozásával (pl. használó személyek számának korlátozásával) az igénybevétel csökkentés is elérhető. Ilyen eset fordulhat elö ha $\alpha_{\text {eff }}$ értéke az alsó és felső küszöb értékek közé esik és nincs mód egy egyszerü, költségarányos megerősítés végrehajtására. Azonban ezt a helyzetet a tulajdonosnak is el kell fogadnia, itt is érvényesülnie kell annak az elvnek. hogy akié a haszon azé a felelősség.

A minimális $\alpha_{\min }$ és az elfogadott $\alpha_{\text {adm }}$ küszöb értékei az alábbiak, az épület fontossági osztálya és tovább használat időtartama szerint.

Az alsó $\alpha_{\min }$ és felső $\alpha_{\text {adm }}$ küszöb értékek
\begin{tabular}{|c|c|c|c|c|}
\hline $\begin{array}{l}\text { Tovább } \\
\text { használat } \\
\text { élettartama }\end{array}$ & \multicolumn{2}{|l}{$\begin{array}{l}\text { Épület fontossági osztá- } \\
\text { lya I. és II. }\end{array}$} & $\begin{array}{l}\text { Épület fontossági } \\
\text { osztálya III. és IV. }\end{array}$ \\
\hline & $\alpha_{\text {adm }}$ & $\alpha_{\text {min }}$ & $\alpha_{\text {adm }}$ & $\alpha_{\text {min }}$ \\
\hline${ }^{3} 80$ év & 0,83 & 0,25 & 0,90 & 0,40 \\
60 év & 0,80 & 0,25 & 0,86 & 0,40 \\
40 év & 0,72 & 0,25 & 0,79 & 0,40 \\
20 év & 0,52 & 0,25 & 0,64 & 0,40 \\
10 év & 0,38 & 0,25 & 0,44 & 0,40 \\
\hline
\end{tabular}

A táblázat grafikon formájában:

$\alpha_{\min }$ és $\alpha_{\text {adm }}$ küszöb értékeinek grafikonja a teljesülési tényezö $\alpha_{\mathrm{eff}}$ és tovább használat függvényében.

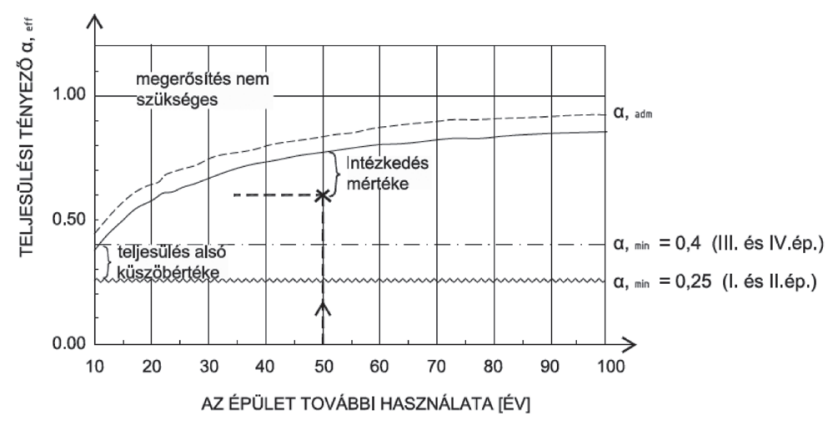

A nem teljesülés esetében leolvasható, hogy milyen mértékü intézkedés (megerősítés) szükséges a teljesülés eléréséhez.

A követelmények nem teljesülése estében a fenti engedményt elsősorban a szeizmikus tervezési állapotra célszerü csak alkalmazni, mert ekkor az MSZ EN 1998-3 szabvány szerint elfogadható az SD állapot (jelentős károsodás, az épület nem dőlhet össze, a menekítés biztosított, a helyreállítás nem gazdaságos).

Az ésszerü kockázat vállalásánál azonban nem elegendő egyedül csak a tapasztalati tudásunkra támaszkodni, szükséges hogy tisztában legyünk az esetlegesen bekövetkezö kár mértékével, az elérhető elöny arányban van-e a bekövetkező kárral, illetve, illetve bizonyosak legyünk benne, hogy az aránytalanul súlyos kár bekövetkezését (az összeomlás állapot előfordulását) kizártuk. Ennek mérlegelésére szolgáltat segítséget a mellékelt diagram és a küszöb értékeket ismertető táblázat az erőtani követelmények nem teljesülését mutató $\alpha_{\text {eff }}$ értékekre $\left(R_{d} / E_{d}\right)$.

Statikus tervezési állapot eredményeinek értékelésénél ezzel az engedménnyel ne éljünk, ilyen esetben a terhelések felülvizsgálata ( a tényleges funkcióhoz igazított állandó és hasznos terhelések, a kapcsolódó parciális tényezők felülvizsgálata (FORM method) segítségével ismételhetjük meg az ellenőrzést (lásd Kovács, at all 2012, és BetonKalender 2009). Amennyiben ezen pontosítások sem eredményezik a követelmények teljesülését, úgy a tartószerkezet megerősítése válik szükségessé.

\section{7. ÖSSZEFOGLALÁS}

Az épületek épületszerkezetei, tartószerkezeti és gépészeti rendszeri a használat során nem egyidőben és egyformán avulnak el. Tartószerkezeteink általában 50 éves élettartamra vannak tervezve, ami az előbb említett rendszerek élettartamát általában jóval meghaladó. A használati funkciók változása is indokolhatja a felújítást és átépítést. Ezért egy ilyen beavatkozás elött akár gazdasági, akár müemléki, akár környezet kímélet miatt a tartószerkezet állapotának megismerése szükséges.

Az átépítések és felújítások általános célja, hogy a meglévő épületet -a funkció megtartásával, vagy annak jelentősebb módosításával - hosszabb távon tovább használhassák, pl. újabb 50 éven át összhangban a szabványi elvárással.

Ezért az átépítések és felújítások során a meglévő épületek tartószerkezeteit erőtani szempontból részletesen vizsgálni kell, hogy azok biztonságos, hosszabb távú müködése biztosított legyen. Ennek alátámasztására állapotmeghatározó statikai szakvélemény készítése szükséges. A korábbi időszakban általános gyakorlat volt az ide kapcsolódó Müszaki Irányelv használata (MI-15011-1988 és utóbb TSZ 01-2013 Müszaki szabályzat). Ezen előírások használatát ma csak előzetes vélemény kialakításához javasoljuk, a végleges szakértői álláspont kialakítása az új jogszabályok és szabványok figyelemebe vételével kell hogy történjen.

Cikkünk bemutatja a feladathoz kapcsolódó újjogszabályokat és csatlakozó újszabványokat és ezekkel egységbe foglalja az állapot meghatározó statikai szakvéleménynél szükséges teendőket. A szakvélemény készítésénél, a jelenleg érvényes követelmények teljesítésének ellenőrzésekor a statikus szakértőnek igen összetett feladata van, kezdve az épülethez kapcsolódó iratok, tervek, egyé dokumentumok felkutatásától, a helyszíni vizsgálatokon át az ellenőrző statikai számítások elvégzéséig és az épület minősítése alapján az épület további használati lehetösége feltételeinek rögzítéséig.

A szakértő a helyszini vizsgálatok értékelése, az épület általános minösitése, a tartószerkezetek tüzvédelmének 
állapota, az ellenörző erőtani számitás eredményei együttes értékelése alapján hozhat megalapozott döntést, illetve tehet javaslatot az ésszerü kockázat vállalására számos paraméter és körülmény ismeretében és azok mérlegelésével.

Mindezen tények meghatározása a szakértőt igen komoly feladat elé állítják és a megállapításai nagy felelőséggel járnak, mert a tartószerkezet viselkedésének kifürkészése a vizsgálat során (mert igen sok esetben „eltakart” tartószerkezetről van szó) sokkal bonyolultabb, mint egy technikai berendezésröl eldönteni, nem működik, gazdaságtalanul müködik és cseréjük ki. Ezért is bír kiemelet jelentőséggel a korábbi tartószerkezeti tervek felkutatása, illetve olyan szintủ feltárások végzése, melyek az ellenőrző számítás végzéséhez szükségesek kellő alapokat és ismereteket megadják.

A tartószerkezeti szakértő minden megállapítása jelentős az épület további élete szempontjából, mert a hosszabb távú használathoz az előírt biztonságot garantálni kell akár egy gazdaságos megerősítési javaslat kidolgozása árán is (pl. merevítés és födémtárcsa megerősítése, a födémek terhelhetőségének növelése, vagy egy-egy tartószerkezeti elem megerősítés által). Tanácsos az ilyen intézkedéseket az áttervezés elsőtervezésifázisban a Tulajdonos (Megbízó) tudomására hozni, mert így számos kellemetlenség válik elkerülhetővé a kivitelezés időszakában, melyek az egész projekt megvalósulását is veszélyeztethetik.

Az épületek átépítése és felújitása során készítendő állapot meghatározó statikai szakvélemény legfontosabb és nem nélkülözhető részét az ellenőrző erőtani számítás képezi.

Az ellenőrző erőtani számításoknak ki kell terjednie a statikus és szeizmikus terhelési állapotok ellenőrzésére, amit az épületek kockázati besorolása, a helyszíni vizsgálatokra támaszkodó számítási modellek, a jövőbeni terhelések befolyásolnak. Itt különös jelentőséggel bír az épület szeizmikus terhelésének megválasztása, szeizmikus besorolása, amihez jelentős segítséget nyújt az MSZ EN 1998-3 szabvány és annak Nemzeti Melléklete.

A szakértőnek a számítás alapján választ kell adnia arra, hogy a meglévő tartószerkezet összessége, vagy annak elemei képesek-e az épület hosszabb távú biztonságos müködését garantálni, illetve milyen megerősítések szükségesek ehhez, az új funkciók szerint követelmények teljesítéséhez.

Külön figyelmet kell fordítani azon épületekre melyeknek függőleges teherhordó rendszerük, falazott és födém rendszerük acélgerendákkal kombinált. Az 1880-1925 közötti időszakban számos épület készült ilyen tartószerkezeti rendszerrel. A födémek jelentős rugalmas alakváltozással és igen rossz rezgéstani ellenállással rendelkeznek, ami javítás (megerösítés) nélkül a tovább használat során kellemetlen hatásokat okoz.

Vasbetonszerkezetek esetében a tartóssági követelmények szempontjából a repedések mértékét szükséges elemezni.
Hasonlóan az acélszerkezeteknél a korrózió mértéke lehet jelentős befolyással az épület állékonyságára és tartósságára.

A megerősítendő szerkezetekre vonatkozó javaslat is legyen része az állapot meghatározó szakvéleménynek amennyiben az szükséges.

A szeizmikus állapotra végzett ellenőrző számítás során olyan eredményre is juthatunk, hogy az épület nem teljesíti a követelményeket. Ide kapcsolódóan bevezettük az un. nem teljesülési hányadost (az igénybevételeknéll $\alpha_{\mathrm{eff}}=\mathrm{R}_{\mathrm{d}} / \mathrm{E}_{\mathrm{d}}$ vagy az alakváltozásoknál $\left.\alpha_{\mathrm{eff}}=\mathrm{w}_{\mathrm{Rd}} / \mathrm{w}_{\mathrm{E}}\right)$, melyhez kapcsolódóan az épület tovább használati idötartamát korlátozni szükséges, vagy az épület megerősítéséről kell gondoskodni.

\section{HIVATKOZÁSOK}

Kovács, T., Szalai, K., Balázs, L., Gy. (2012), „Betonszerkezetek teherbírási vizsgálata a globális biztonsági tényezős eljárással”, VASBETONÉPÍTÉS, 2012/3, pp 77-87.

Beton Kalander (2009), „Analyse bestehender Tragwerke auf Grundlage vorhandener Planungsdokumente", pp. 17-30.

Beurteilung der Erdbebensicherheit bestehender Gebaude. Konzept und Richtlinien für die Stufe 3. Wegleitungen des BWG-Biel, 2005.

SIA D 0211 (2005) Überprüfung betehender Gebaude bezüglich Erdbeben, Einführung in das Merkblatt SIA 2018. Dokumentation, Schweizer Ingenieur- und Architektenverein, Zürich

MSZH, (1988), „Épületek megépült teherhordó szerkezeteinek erőtani vizsgálata", MI 15011-1988

Dulácska. E., Korda J., Körmöczi E., Müszaki szabályzat, Épületek megépült teherhordó szerkezeteinek erőtani vizsgálata és tervezési elvei, TSZ 012013, Magyar Mérönki Kamara

Magistrat der Stadt Wien, „Statische Vorbemessung” 2008 März.

MSZ EN 1998-3.," Tartószerkezetek tervezése földrengésre, 3. rész Épületek értékelése és helyreállitása"

Várdai A. (2020), „A megépült vasbetonszerkezetek megbízhatósági értékelése a fib Bulletin 80 alapján”, VASBETONÉPÍTÉS 2020/2, pp. 43-52.

Dr. Almási József (1940) okl. építőmérnök (1964), műszaki doktor (1972), 29 évi kutatás a BME Vasbetonszerkezetek Tanszékén, több mint 200 szakvélemény készítője. 2002-ben Palotás László-díjat kapott. A BME címzetes egyetemi docense.

Varvasovszky Péter (1977) okl. építőmérnök (2001), partner és vezető tervező az APSE Kft-nél, számos irodaház, bevásárlóközpont, ipari épület statikus tervezője. Fő érdeklődési területe a tartószerkezetek tervezése földrengéses hatásokra.

\section{HOW TO CREATE THE STATICAL EXPERTISE ABOUT EXSISTING BUILDINGS}

József Almási - Péter Varvasovszky

One of the most important design elements for the reconstruction and renovation of an existing building is the static expertise that determines the condition of the supporting structure. To do this, we need to know the current legal and standard requirements. The static opinion should be based on field inspections and tests, to know the fire protection capability of the supporting structure and the results of the structural calculation. In our opinion, without the latter, the classification of the static condition of the building can not be justified. It should be borne in mind that the primary purpose of the expert opinion is to state whether or not the building can be used safely in the long term and what measures are needed for longer-term use. 